\title{
Konference Univerzity a udržitelný rozvoj
}

\section{Jana Dlouhá}

\section{Envigogika 12 (2) - Informace/ Information}

Publikováno / Published 28. 12. 2017

DOI: $10.14712 / 18023061.558$

\begin{abstract}
Abstrakt
Centrum pro otázky životního prostředí UK si letos připomnělo 25 let od svého založení. Při této př́ležitosti se 21. listopadu 2017 ve Vlasteneckém sále Karolina konala konference Univerzity a udržitelný rozvoj, jež se věnovala aktuálním problémům současného světa a zapojení univerzit do snah o jejich nápravu.
\end{abstract}

\section{Klíčová slova}

Konference; věda udržitelnosti; univerzity

\begin{abstract}
The Charles University Environment Centre reminded this year 25 years since its founding. On this occasion, on November 21, 2017, a conference "Universities and Sustainable Development was held at the Patriotic Hall of the historical building of Charles University. Conference focused on the current problems of the contemporary world and the involvement of universities in their efforts to correct them.
\end{abstract}

\section{Keywords}

Konference; sustainability science; universities 
Konference byla uspořádána k 25. výročí založení Centra pro otázky životního prostředí UK dne 21. listopadu 2017 ve Vlasteneckém sále Karolina.

Centrum pro otázky životního prostředí UK si letos připomnělo 25 let od svého založení. Při této př́ležitosti uspořádalo mezinárodní konferenci, jež se věnovala aktuálním problémům současného světa a zapojení univerzit do snah o jejich nápravu. Otázky, jak ochránit zdroje pro život na planetě, přitom si však zachovat určitý blahobyt, musí vědci řešit ve spolupráci s politickou sférou. Konference byla př́ležitostí toto téma prodiskutovat: poskytla přiležitost významným akademickým i dalším společenským aktérům, aby se $\mathrm{k}$ němu vyjádřili. V dopolední části programu vystoupil rektor Univerzity Karlovy Tomáš Zima, který zdůraznil úlohu této instituce jako společensky odpovědné univerzity, která koncept udržitelného rozvoje bere velmi vážně, jelikož problematika se prolíná do všech sfér života občana. Prorektor pro vědeckou činnost Jan Konvalinka pak zdůraznil, že Univerzita Karlova považuje činnost Centra pro otázky životního prostředí i samotnou konferenci za př́spěvek do naplňování Dlouhodobého záměru Univerzity Karlovy pro roky 2016 - 2020. Státní tajemník pro evropské záležitosti, pan Aleš Chmelař, vyzdvihl především úlohu vědců v dnešním "postfaktickém" světě, kdy jsou objektivní vědecké důkazy často účelově zpochybňovány. Zahraniční řečníci, Maik Adomßent a Arthur Lyon Dahl, pak hovořili o možnostech a limitech společenské angažovanosti univerzit - ze své podstaty vědeckých a autonomních institucí - a představili potenciální způsoby jejich zapojení do procesů udržitelného rozvoje.

Součástí odpoledního programu byla diskuse týkající se perspektiv mezioborové spolupráce ve vědeckém výzkumu a vzdělávání, vedená mezi představiteli tzv. Rámcové dohody pražských vysokých $v$ environmentální oblasti. $V$ závěru tohoto přátelského setkání si COŽP UK zrekapitulovalo svou vědeckou i jinou činnost za posledních 5 let své existence, a zástupci tří oddělení Centra představili výsledky nejnovějších výzkumných programů. Konference byla zakončena neformální debatou při pohoštění v historických prostorách Karolina.

Konference "Univerzity a udržitelný rozvoj tak byla určitým milníkem ve směřování Univerzity Karlovy $\mathrm{k}$ udržitelnosti, a tím také v naplňování základního poslání Centra pro otázky životního prostředí. Poprvé se na tak širokém (celouniverzitním) fóru podařilo rozvinout debatu na téma odpovědné vědy, která je významným faktorem udržitelného rozvoje, a zapojit do ní nejen akademické činovníky, ale i představitele naší politické scény. Konference navíc zprostředkovala setkání vrcholných zástupců 4 z 5 pražských univerzit, které se již tradičně zavazují v této oblasti ke spolupráci, a tento svůj závazek hodlají v př́štím roce obnovit nebo dokonce rozširíit. Koncept vědy udržitelnosti, který je často pokládán za př́liš abstraktní a nepraktický, pak byl demonstrován na konkrétních výsledcích, kterých dosáhli výzkumníci Centra, a to jak vědeckých, tak i co se týče jejich společenské angažovanosti. Podařilo se také utužit "komunitu přesvědčených" a snad i přesvědčit nové její členy z řad studentů, což málokdo vnímal jako společenskou povinnost. Valná část z téměř 90 účastníků totiž zůstala až do konce, takže i debaty v kuloárech, při večerním neformálním setkání, Ize započítat $\mathrm{k}$ užitečným a navíc přijemným výsledkům této akce.

Na tomto odkazu je projev rektora UK Tomáše Zimy - originální text projevu najdete níže. Další materiály - prezentace, videa a fotografie z konference - najdete na_stránkách COŽP UK, 


\title{
Příloha - Úvodní slovo pana rektora UK
}

\author{
Vážení kolegové a kolegyně,
}

Vítám Vás na konferenci k 25. výročí založení Centra pro životní prostředí. Jsem rád, že se pořádá tato akce, jež se věnuje tématu udržitelného rozvoje a je př́spěvkem do naplňování Dlouhodobého záměru Univerzity Karlovy 2016-2020. Univerzita Karlova je společensky odpovědná univerzita, proto koncept udržitelného rozvoje bere velmi vážně, jelikož téma se prolíná do všech sfér života občana. Jak zachovat zdroje pro život na planetě a zachovat si blahobyt jsou otázky, které mají řešit kromě politické sféry také univerzity - ze své podstaty vědecké a autonomní instituce.

Jsme si plně vědomi, že univerzity, přestože akademická půda je chráněna před politickými vlivy, nemohou zůstat zcela stranou společenského dění - nebo politické dění ve společnosti dopadne i na ně. Důkazem toho jsou historické události, které jsme si právě v minulých dnech připomněli: výročí zavření českých vysokých škol nacistickým režimem a brutální zásah proti studentům v r. 1939, i výročí sametové revoluce z r. 1989, která po desítkách let osvobodila naše vysoké školství z ideologického sevření, postihující osobnosti, jež se mu nepovolily, zákazem vědecké, tvůrčí a pedagogické činnosti. Je tedy jasné, že právě v dobách svobody musí také akademičtí pracovníci podle svých sil a možností formovat společenské prostředí dříve, než je na pozitivní změny pozdě, a nepříznivý vývoj již nelze zastavit.

Politická rozhodnutí se dnes ovšem dělají jinak, než v minulosti. Především se týkají daleko širšího okruhu otázek. Např́klad se ukázalo, a to je zkušenost vlastně nedávné minulosti řádově desítek let, že prostředí Země je utvářeno (a přetvářeno) velmi významně i lidskou činností. Současná kultura toto prostředí nejen kultivuje, ale technickými prostředky také devastuje. Samovolné prírodní procesy se dostaly do defenzivy, a tak se objevila nutnost je bedlivě sledovat, kontrolovat a usměrňovat, aby se zajistila dostatečná regenerace, obnova přírodních systémů, které pak umožňují i zdravý život člověka. Problému monitorování, kontroly a regulace těchto procesů se pro jeho složitost ujala věda, která si zde ovšem nevystačí se zavedenými obory; potřebné vědecké metody vznikají ve vzájemné interakci více disciplín a podle potřeb praxe.

Dovolte mi zde uvést paralelu s mým vlastním oborem, jimž je věda lékařská. Pro zajištění zdraví Země potřebujeme diagnostiku, nové léčebně postupy, prevenci. Musíme však také dosáhnout toho, aby se pacient léčil, nepřestal přitom ale živit svou rozrůstající se lidskou rodinu. Jeho léčba je nejen složitá, drahá, a měla by byt komplexní, ale v tomto případě jde o pacienta, za kterého my sami musíme rozhodnout, jaké postupy aplikovat, a zajistit, aby je aplikoval. To je úkol pro politiky, zde jsou lékaři a terapeuti u konce se svou mocí uzdravit nemoci, jejichž původ je v překročení vlastních limitů. A věřte, že vidět pacienta strádat bez dostupné léčby jen proto, že není, kdo by ji uplatnil, kdo by na sebe vzal tuto odpovědnost, je velmi frustrující. I to se tedy stává úkolem pro vědce a učitele: přesvědčit společnost o tom, že pravda pořád je a platí, a to i v dnešním „post-faktickém" světě, a že pravda vědecká může nejen předvídat budoucnost, ale také jí pomáhá úspěšně čelit.

Naznačil jsem zde nejméně dvě nové oblasti, v nichž se výzkum intenzivně rozvíjí: environmentální vědy, které zajištují diagnostiku a navrhují léčebné postupy, a využití vědeckých metod a údajů pro politické, tzv. evidence-based, rozhodování. Centrum pro otázky životního prostředí se věnuje oběma, za čtvrtstoletí své existence se postupně vyvíjí směrem ke druhé z nich. Součástí politických rozhodnutí jsou potom i technická řešení: ta 
vznikají na základě určitých principů (založených hodnotově, na konceptu trvale udržitelného rozvoje) a realizují se ve spolupráci těch, kteří mají potřebné znalosti a schopnosti o možnostech této spolupráce ale budou hovořit zástupci dalších vysokých škol později.

Spolu s odpovědností, kterou současná věda přijímá za stav společnosti i prostředí, v němž žijeme, se tato věda sama mění. $O$ jejích proměnách se více dozvíte $v$ dalších částech programu této konference - $z$ naší strany je potřeba usilovat o to, aby instituce s dlouholetou tradicí, jakou je Univerzita Karlova, dokázala tyto změny plně vstřebat a také k nim aktivně přispět. Na tomto místě chci poděkovat Centru pro otázku životního prostředí, jeho zakladatelům i současným protagonistům, že se tímto směrem vydali, a nové vědecké oblasti (přes počáteční nedůvěru $v$ jejich opodstatněnost) rozvíjejí. Velmi také doufám, že zástupci důležitých společenských aktérů, kteří se sešli v tomto sále ke společné poradě nejen o budoucnosti jednoho z institutů Univerzity Karlovy, ale především o naší společné budoucnosti, nás $v$ tomto úsilí podpoří. 